\title{
Daugiafunkcinio miško vertinimas pajamų kapitalizavimo metodu
}

\author{
Stasys Mizaras ${ }^{1}$, \\ Marius Kavaliauskas², \\ Gintautas Činga ${ }^{2}$ \\ ${ }^{1}$ Lietuvos agrariniu ir mišku \\ mokslu centro filialas, Mišku institutas, \\ Liepu g. 1, LT-53101 Girionys, Kauno r. \\ ${ }^{2}$ Aleksandro Stulginskio universitetas, \\ Studentu g. 11, \\ LT-53361 Akademija, Kauno r. \\ El.paštas: stasys.mizaras@gmail.com
}

Pajamų kapitalizavimas yra vienas iš turto vertinimo metodų. Metodo taikymas miškų vertinimui yra specifiškas dèl ilgo miškų auginimo laikotarpio bei miškų daugiafunkciškumo.

Ekonominio vertinimo tikslais tyrime taikyta tokia Lietuvos miško ištekliu ir funkcijų klasifikacija: mediena, miško grybai, miško uogos, miško vaistiniai augalai, medžiojamieji gyvūnai, miško rekreacinès funkcijos, $\mathrm{CO}_{2}$ naudojimas, biologinès įvairovès išsaugojimas, vandenų apsauga, priešerozinès funkcijos, laukų apsauginès funkcijos, sanitarinès bei higieninès funkcijos.

Lietuvos miškai pagal medieną ịvertinti dviem metodais: miško įmonių grynųjų pajamų kapitalizavimo ir pagal Faustmano formulę. Pagal nemedieninius miško išteklius ir funkcijas miškai vertinti dviem etapais:

1) metinès naudos ịvertinimas;

2) grynujjų pajamų apskaičiavimas ir kapitalizavimas.

Žaliavinių nemedieninių miško išteklių naudojimo metinès pajamos ìvertintos remiantis jų rinkos kainomis. Miško rekreacinių išteklių vertinimui taikytas kontingentinio vertinimo metodas. $\mathrm{CO}_{2}$ sunaudojimui vertinti - taršos leidimų kainos. Biologinès ịvairovės išsaugojimo funkcijai - alternatyviųjų išlaidų metodas. Vandenų apsauginèms funkcijoms, priešerozinėms ir sanitarinėms bei higieninèms miško funkcijoms - išvengtų išlaidų bei produktyvumo pokyčių metodai.

Nustatyta Lietuvos miškų kompleksinè vertè - 26,7 mlrd. Lt (medieną vertinant pagal Faustmano formulę). Miškų vertẻ pagal nemedieninius išteklius ir funkcijas sudare $36,9 \%$.

Raktažodžiai: miškas, ištekliai, funkcijos, pajamų kapitalizavimas

\section{IVADAS}

Miško, kaip turto, vertei nustatyti gali būti taikomi šie Tarptautinio turto vertinimo standartų komiteto pripažinti ir LR turto ir verslo vertinimo pagrindų ịstatyme numatyti metodai:

- palyginamosios vertès (pardavimo kainos analogų) metodas, kurio esmè yra palyginimas, t. y. rinkos vertė nustatoma palyginus analogiškų objektų faktinių sandorių kainas, kartu atsižvelgiant i nedidelius vertinamo turto bei jo analogo skirtumus;

- atstatomosios vertès (kaštų) metodas, kurio pagrindas yra skaičiavimai, kiek kainuotų atkur- ti esamos fizinès būklès ir esamų eksploatacinių bei naudingumo savybiu objektus pagal vertinimo metu taikomas darbų technologijas bei kainas;

- naudojimo pajamų vertes (pajamų kapitalizavimo) arba piniginių srautų diskonto metodas, kai turtas vertinamas ne kaip įvairaus turto suma, bet kaip verslo objektas, duodantis pelną. Metodo pagrindą sudaro būsimų pinigų srautų prognozès ir jų dabartinè vertè.

Paminètų metodų taikymas Lietuvos miškų vertinimui yra problematiškas. Dèl mažos miškų rinkos ir informacijos apie sandorius trūkumo palyginamosios vertès metodas taikomas retai. Atstatomosios vertès metodas gali būti taikomas miško 
želdinių vertinimui, o vertinant vyresnius medynus pagal jų auginimo išlaidas prarandamas ryšys su medynų vartojamąja verte. Todèl diskontuotų grynųų pinigu srautų skaičiavimas yra vienintelis būdas bandyti nustatyti tikrają (teisingą) miško vertę (faire value).

Miškų ekonominio vertinimo pagrindus taikant grynųjų pajamų kapitalizavimo metodą sukūrè vokiečių miškininkas M. Faustmanas 1849 m., pasiūlęs miško žemès vertinimo formulę, pagal kurią nustatomos grynosios pajamos už medieną, kurių gali tikètis žemès savininkas, savo sklype pradejęs auginti mišką. Naudojant miško žemès vertinimo formulę diskonto metodu galima įvertinti ịvairiu laikotarpiu ir pajamas, ir išlaidas. Tačiau šis plačiausiai taikomas miško ūkyje naudojimo pajamu kapitalizavimo metodas turi savų trūkumų ir ribotumų. Metodas remiasi prielaidomis (miško naudojimo ateityje apimtys, miško išteklių ateities kainos, miško išteklių naudojimo ateities išlaidos, diskonto norma), kurias pagrịsti sudètinga. Šių veiksnių pasirinkimas daro dideli poveikị nustatomai miškų vertei. Analizuodami miškų vertinimo ir apskaitos sistemas J. N. Hogg ir H. A. Jöbst (2005) teigia, kad pasaulyje sukurta daug metodų, siekiančiu „pagauti“ miškų vertę ir jos pokyčius, tačiau tikslūs ir tinkami metodai lieka „nepagaunami“.

Būtina pažymèti, kad miškams būdingas didelis daugiafunkciškumas. Tenkindamas ekologines, ekonomines bei socialines reikmes, miškas teikia medieną ir kitus miško produktus, taip pat miškas, sudarydamas daugelio gyvūnijos ir augmenijos rūšių buveines, stabdydamas dirvos eroziją, absorbuodamas anglies dvideginį bei grynindamas orą, kaupdamas angli biomasëje, kartu mažindamas šiltnamio efektą sukeliančių dujų kiekị atmosferoje, saugodamas gruntinius ir paviršinius vandenis, suteikdamas galimybę žmonèms poilsiauti, yra esminis ekologinès pusiausvyros veiksnys (Nacionalinè miškų ūkio sektoriaus plètros 2012-2020 metu programa, 2012).

Esant tokiai didelei miško išteklių ir funkcijų ìvairovei, jų ekonominis vertinimas yra labai sudètingas. Dalis miško išteklių yra perkami bei parduodami - tai yra rinkos objektai. Kiti miško ištekliai ir funkcijos naudojami nemokamai. Lietuvoje tai būtų miško grybai, uogos, vaistiniai augalai, poilsiavimas miškuose, $\mathrm{CO}_{2}$ naudojimas, biologinès ịvairovès apsauga, vandenų, oro bei dirvožemių apsauga.

Lietuvoje pirmą kartą 1973-1978 m. miškų kompleksinio vertinimo, apimančio medienos, ne- medieninių miško išteklių, miško apsauginių ir rekreaciniu funkciju vertinimą, metodiką parengè Lietuvos žemès ūkio akademijos, Lietuvos mokslu akademijos Ekonomikos instituto ir Geografijos skyriaus, Lietuvos mišku ūkio mokslinio tyrimo instituto, Lietuvos miškotvarkos įmonés darbuotojai (Ekonomikos institutas, 1975). Po nepriklausomybès atkūrimo (1990), iš esmès pasikeitus ekonominiams santykiams, atsirado miškų ekonominio vertinimo metodų, atsižvelgiančių ì rinkos ekonomikos ypatumus, poreikis.

Šių tyrimų tikslas - juvertinti Lietuvos miškų daugiafunkciškumą miško naudojimo pajamų kapitalizavimo metodu. Tyrimo tikslui pasiekti keliami šie uždaviniai:

1. Adaptuoti naudojimo pajamų kapitalizavimo metodą mišku vertinimui.

2. Parengti miško išteklių ir funkcijų klasifikaciją, tinkamą miškų ekonominiam vertinimui.

3. Pritaikyti atskirų miško išteklių ir funkcijų ekonominio vertinimo metodikas.

4. Atlikti Lietuvos daugiafunkcinių miškų ekonominị vertinimą.

\section{TYRIMŲ METODAI IR SĄLYGOS}

Pajamų kapitalizavimo metodas. Miškai, kapitalizuojant iš jų gaunamas grynąsias pajamas, vertinami pagal formulę:

$$
M_{v}=\frac{G_{p}}{p}
$$

$M_{v}-$ miškų verté;

$G_{p}$ - vidutinès metinès grynosios pajamos iš miško ūkinès veiklos;

$p$ - palūkanų norma, vieneto dalimis.

Miškų vertinimui pajamų kapitalizavimo metodu taikant Faustmano formulę, ją papildžius dabartinių medynų vertinimu, o būsimų medynų vertinimą pradedant nuo dabartinių medynų iškirtimo metų gauname:

$$
M_{m}=\frac{A_{T}}{(1+p)^{T-t}}+\frac{A_{T}-C \times(1+p)^{T}}{\left[(1+p)^{T}-1\right] \times(1+p)^{T-t}}-\frac{V}{p} ;
$$

$M_{m}$ - miško vertė pagal medieną;

$A_{T}$ - pajamų, gaunamų iškirtus $T$ amžiaus medyną, vertė nenukirsto miško kainomis;

$T$ - kirtimo apyvarta (metais);

$C$ - miško atkūrimo (želdinimo, priežiūros ir kt.) išlaidos; 
$V$ - metinès administracijos ir valdymo išlaidos;

$p$ - metinè palūkanų norma vieneto dalimis.

Atlikus algebrinius 2-os formules pertvarkymus, gauname:

$$
M_{m}=\frac{\left(A_{T}-C\right) \times(1+p)^{t}}{(1+p)^{T}-1}-\frac{V}{p} .
$$

Šiose formulèse (2-3) i tarpinio naudojimo kirtimus neatsižvelgiama.

Išaiškinami reikalingi vertinimui rodikliai:

1. Medynų tūrio kirtimo amžiaus vertè nenukirsto miško kainomis $\left(A_{T}\right)$;

2. Miško atkūrimo išlaidos $(C)$;

3. Miškų administravimo ir valdymo išlaidos $(V)$.

Medynų tūrio kirtimo amžiaus $\left(A_{T}\right)$ vertė nenukirsto miško kainomis nustatoma remiantis valstybinèmis nenukirsto miško kainomis, brandžių medynų tūriais ir jų sortimentine struktūra. Miško atkūrimo išlaidos $(C)$ nustatomos pagal jų normatyvinius duomenis (pvz., Riepšas, 2009; LR AM, 2010) arba pagal faktinius miško įmonių duomenis. Miško administravimo ir valdymo išlaidos $(V)$ nustatomos remiantis miškų imonių išlaidomis miško ūkinei veiklai.

Miškai pagal nemedieninius miško išteklius ir funkcijas vertinami taip:

1. Ivertinama metinè miško nauda pagal kiekvieną išteklių arba funkciją.

2. Apskaičiuojamos metinès grynosios pajamos pagal kiekvieną miško išteklių ir funkciją, metinę miško naudą (1 punktas) padauginant iš grynųju pajamų koeficiento.

3. Metinès grynosios pajamos kapitalizuojamos. Miško verte pagal kiekvieną išteklių ir funkciją apskaičiuojama kapitalizuojant metines grynąsias pajamas (2 punktas), t. $y$. jas dalinant iš palūkanų normos vieneto dalimis.

Taikant pajamų kapitalizavimo metodą reikia akcentuoti, kad pinigu srautai yra skaičiuojami begaliniam laikotarpiui ir tai yra didelis metodo taikymo apribojimas, nes visos prielaidos turi būti prognozuojamos begalinei ateičiai.

Diskonto normos parinkimas - neišspręsta ir diskutuojama ekonomikos mokslo problema. Ši diskonto norma lemia šiandieninès ir ateities mišku naudos vertę. Nulinè diskonto norma reiškia, kad šiandieninès ir ateities miškų naudos vertinamos vienodai. Šiuolaikinès darnaus miškų ūkio koncepcijos numato būtinybę suderinti dabarti- nių ir ateities kartų interesus. Visiškai netaikant diskontavimo pažeidžiami dabartiniai interesai, nes pinigu suma dabar yra vienodai vertinama su tokia pat pinigu suma po kelių dešimtmečių. Taikant aukštas diskonto normas pažeidžiami ateities interesai, nes pinigu sumos po kelių dešimtmečių tampa labai mažavertès. Taigi, miškininkystès ekonominès analizès atveju taikytinos socialinès diskonto normos. Rinkos diskonto normos reiškia privatų kontekstą, o socialinès diskonto normos turi remtis visuomeniniu kontekstu - priimdami visuomeninius sprendimus, jaučiame atsakomybę už dabartinę ir ateities kartas. Todèl norint ịvertinti ateities kartų problemas socialinès diskonto normos turètų būti žemesnès už rinkos normas ir, remiantis etinėmis paskatomis, neturètų viršyti 1-3 \% (Čiegis, 2008; 2009).

Mažesnių nei kitose ūkio šakose diskonto normų taikymas miškininkystėje yra dažnas moksliniuose darbuose (Uilliams, 1991; Price, 1993; Klemperer, 1994; Hepburn, Koundouri, 2007; Brukas, Thorsen, Helles, Tarp, 2001; Binkley, 2009; Grege-Staltmane, Tuherm, 2010). Aukščiausios diskonto normos (>7 \%) siūlomos taikyti greitai augančioms medžių rūšims (pvz., Pinus radiata). JAV taikoma 4-8 \%, Skandinavijos šalyse 2-4 \%, Vokietijoje - nulinè diskonto norma (Brukas, Thorsen, Helles, Tarp, 2001). Atlikę diskonto normą lemiančiu veiksnių analizę Lietuvoje, V. Brukas ir kt. (2001) siūlè Lietuvos valstybiniame miškų ūkyje taikyti iki 4 \% diskonto normą. Europos komisijos metodiniuose dokumentuose (EK, 2006) siūloma minimali socialinè diskonto norma $-3,5 \%$.

Yra teorijų, pagrindžiančių mažèjančią diskonto normą ilgejjant diskontavimo laikotarpiui (Weitzman, 1998). Šis principas igyvendintas Jungtinès Karalystès iždo Žaliojoje knygoje, kurioje siūlomos tokios socialinio diskonto normos: 0-30 metu - 3,5 \%, 31-75 m. - 3,0 \%, 76-125 m. - 2,5 \%, 126-200 m. - 2,0\%, 201$300 \mathrm{~m} .-1,5 \%$ ir daugiau nei $300 \mathrm{~m}$. - 1,0\%.

Siekiant nustatyti turto vertę, paremtą rinkos formuojamais rodikliais, reikalinga, kad iš turto gaunami pinigų srautai būtų diskontuojami dabartine rinkos apibrèžta norma (IAS-41). 23-asis verslo apskaitos standartas „Turto nuvertèjimas“ diskonto normai nustatyti siūlo įmonès ilgalaikiu paskolų palūkanų normą ar ilgalaikių Vyriausybès vertybinių popierių diskonto normą, pakoreguotą atsižvelgiant $\mathfrak{i}$ rizikos veiksnius, susijusius 
su įmone ir jos šaka. $2011 \mathrm{~m}$. Lietuvos valstybès skolai esant $38504,7 \mathrm{mln}$. Lt buvo išmokèta palūkanų 1833 mln. Lt arba 4,8\%. Vertinant miškus priimtiniausia būtų taikyti 3-4 \% diskonto normą.

Miško išteklių ir funkcijų klasifikavimas. Miškas yra daugiafunkcinis gamtos darinys, kurio prigimtinès funkcijos (teikti medieną, grybus, uogas, vaistažoles, galimybę poilsiauti, laukų, dirvų, vandenų apsaugą, gyvenamąją terpę augalams ir gyvūnams, gryninti gyvenviečiu orą ir pan.) tampa ištekliais, kai tos funkcijos igauna visuomeninę vertę, t. y. visuomenè pradeda sąmoningai jomis naudotis (Dieterich, 1953; Deltuvas, 2008). Todèl sąvokos „funkcijos“ ir „ištekliai“ gali būti taikomos tiems patiems reiškiniams apibūdinti, tik skirtingu aspektu.

Ekonominio vertinimo tikslams siūloma tokia Lietuvos miško išteklių ir funkcijų klasifikacija: mediena, miško grybai, miško uogos, miško vaistiniai augalai, medžiojamieji gyvūnai, miško rekreacinès funkcijos, $\mathrm{CO}_{2}$ naudojimas, biologinès ìvairovès išsaugojimas, vandenų apsauga, priešerozinès funkcijos, laukų apsauginès funkcijos, sanitarinès bei higieninès funkcijos.

Lietuvos miškai pagal savo išteklius ir funkcijas yra skirtingi. Didžiausią Lietuvos miškų dalị (71,4 \%) sudaro ūkiniai miškai, kurių pagrindinè funkcija pagal Miškų priskyrimo miškų grupèms normatyvus (2001) yra nepertraukiamai tiekti šalies ūkio ir gyventojų reikmėms medieną, laikantis aplinkosaugos reikalavimų ir nenualinant miškų valyti orą, palaikyti gruntinio vandens lygi.

Specialiai miško grybams, uogoms, vaistiniams augalams, medžioklei išskirtų miškų nėra. Šiek tiek specializuota medžioklè. Šių išteklių, kurie gali būti beveik visuose miškuose, naudojimas yra aktualus visuomenei.

Rekreacinių miškų Lietuvoje yra 64,9 tūkst. ha (3,0 \%). Tai miško parkai, kurortų miškai, miestų miškai, rekreaciniai miško sklypai, valstybinių parkų rekreacinių zonų miškai. Rekreaciniuose miškuose poilsiautojų ir kitų lankytojų srautai yra intensyviausi. Rekreacinę funkciją atlieka ir dalis kitų miškų.

Biologinès ìvairovès išsaugojimui daugiausia skirti rezervatų ir draustinių miškai. Jų Lietuvoje yra 280,8 tūkst. ha (12,9 \%). Rezervatų ir draustinių miškai atlieka kompleksą funkcijų (saugomų augalų, gyvūnų, kraštovaizdžio ir pan. apsauga). Biologinès ịvairovès apsaugai dar skirti „Natūra 2000" teritoriju miškai, kertinès miško buveinès, biržèse paliekami biologinès ịvairovès medžiai.
Vandens telkinių apsaugos zonų miškų Lietuvoje yra 145,5 tūkst. ha (6,7 \%). Gruntinit vandens lygi palaiko ir $\mathrm{CO}_{2}$ naudoja visi miškai.

Lietuvoje dar išskiriami laukų apsauginiai, priešeroziniai, kelių apsauginiai miškai. Miestų bei gamyklų sanitarinių zonų miškai atlieka sanitarines bei higienines funkcijas. Tačiau šių miškų plotai nèra dideli. Laukų apsauginių miškų Lietuvoje išskirta 22,2 tūkst. ha (1,0\%), miestų ir gamyklų sanitarinių zonų miškų - 15,0 tūkst. ha $(0,7 \%)$, kelių apsauginių - 2,5 tūkst. ha $(0,1 \%)$. Be to, diskutuotinas kai kuriu miško funkcijų visuomeninis poveikis. Teigiama (Karazija, Vaičiūnas, 2000), kad miškų laukų apsauginès reikšmės, pasireiškiančios mikroklimato gerinimu bei lauku derlingumo didinimu, aktualumas Lietuvos sąlygomis abejotinas. Turimi duomenys rodo netgi neigiamą ittaką kai kurioms lauko kultūroms.

Miško išteklių ir funkcijų naudos ekonominio vertinimo metodai. Vienas iš svarbiausių miškų ekonominio vertinimo pajamų kapitalizavimo metodų etapų yra gaunamos iš miško naudos (pajamų) įvertinimas. Tyrime taikyti literatūroje skelbti miško išteklių bei funkcijų vertinimo metodai.

Miškų naudos vertinimo metodai skirstomi i dvi grupes:

1) kai miškų teikiama nauda yra rinkos objektas;

2) kai teikiama nauda nera tokiu objektu.

Rinkos kainos taikomos vertinant rinkoje dalyvaujančius miško produktus ir paslaugas. Nedalyvaujančios rinkoje miškų naudos vertinimui taikomi kontingentinis, kelionès išlaidų, hedoninio ¡kainojimo, gamybos funkcijų bei išlaidų metodai (Merlo, Craitoru, 2005).

Rekreacinès miško funkcijos vertinimo taikant kontingentini metodą esmè yra hipotetinès rinkos rekreacijai nustatymas, kai vartotojo klausiama, kiek jis sutiktų mokèti už poilsiavimą miške. Rekreacinès miško funkcijos vertinimo tvarka kontingentinio vertinimo metodu yra tokia: nustatoma, kokias paslaugas vertina jas naudojantys gyventojai; nustatomas apklausos atrankos dydis; parengiama apklausos metodika, atliekamos bandomosios apklausos, sudaromas klausimynas; atliekama apklausa; nustatomas vidutinis poilsiavimo dienos vertinimas; nustatomas bendras poilsiautojų skaičius; apskaičiuojama vertinamų mišku rekreacinès funkcijos metinè vertè.

Anglies dvideginio sunaudojimo vertinimo kriterijus yra anglies kiekio, sukaupiamo miškuose 
per metus, vertè. Nustatyta (Miškininkystè, 1979), kad $1 \mathrm{~g}$ augalų sausos substancijos pagaminti reikia $0,5 \mathrm{~g}$ anglies, o tai atitinka $1,83 \mathrm{~g} \mathrm{CO}_{2}$. Anglies dvideginio sunaudojimo metinè vertè nustatoma taip:

$$
V_{\mathrm{CO}_{2}}=Z \times k_{s} \times 1,83 \times K_{\mathrm{CO}_{2}} ;
$$

$V_{\mathrm{CO}_{2}}$ - anglies dvideginio sunaudojimo metinè vertè Lt;

$Z$ - medynų tūrio prieaugis $\mathrm{m}^{3}$;

$k_{s}$ - medienos perskaičiavimo ị sausą biomasę koeficientai $\mathrm{m}^{3} / \mathrm{t}$;

$K_{\mathrm{CO}_{2}}$ - anglies dvideginio kaina $\mathrm{Lt} / \mathrm{t}$.

Miškų biologinès ịvairovès išsaugojimo funkcija vertinta alternatyvių išlaidų metodu. Alternatyvias išlaidas sudaro prarasta nauda, palyginus pasirinktąją išteklių naudojimo alternatyvą su atmestąja (Martinkus, Žilinskas, 1997). Tai kirtimų vertès sumažèjimas dèl saugomų teritorijų išskyrimo.

Vandenų apsauginès funkcijos susideda iš švaraus vandens nuotekio suformavimo, vandens nuotèkio padidinimo, paviršinio nuotèkio pervedimo ị gruntinius vandenis. Švaraus vandens nuotèkio suformavimo apsaugant vandenis nuo užteršimo vertinimo etapai:

1. miškai skirstomi ị smèlio lygumas, kitas lygumas, kalvotas žemes;

2. pagal vandenų atskiedimo nuotekiu iš miškų normatyvus (Pauliukevičius, 1974, 1975) apskaičiuojamas vandenų atskiedimas;

3. nustatoma nutekamųų vandenų biologinio išvalymo kaina;

4. ịvertinama vandenų atskiedimo miško funkcija ( 2 punktas $\times 3$ punktas).

Vandens nuotèkio padidinimas vertintas pagal vandens nuotèkio padidejimą miškingose teritorijose ir vandens kainą. Paviršinio nuotèkio pervedimas $\mathfrak{i}$ gruntini vertintas priemolio ir molio dirvožemiuose augančiuose miškuose pagal paviršinio nuotèkio pervedimą i gruntinius vandenis per metus ir vandens kainą. Priešerozinè funkcija vertinta pagal miškų sulaikomų išplaunamų iš dirvožemio cheminių medžiagu kiekius ir trąšu kainas. Sanitarinès bei higieninès miško funkcijos - tai deguonies išskyrimas, dulkių sugèrimas, fitoncidų išskyrimas. Šiuo metu teigiama (Homo Sanitus, 2012), kad medis ar kuris nors kitas žalias augalas, gyvendamas išskiria tiek deguonies, kiek vèliau supūdamas, sudegdamas ar kitu būdu suskaidomas sunaudoja. Todèl ši funkcija ekono- miškai nevertintina. Medžiai, turẻdami didelị lapu paviršiaus plotą, tarsi filtrai surenka iš oro aerozolius ir dulkes. Nustatyta, kad 1 ha eglyno per metus sulaiko 30 , pušyno - 35 , bukyno - 68 tonas dulkių (Miškininkystė, 1979). Dulkių sulaikymo miškų funkcija vertinta pagal dulkių valymo taikant specialią techniką išlaidas.

Bendra (kompleksinè) miškų vertè nustatyta sumuojant vertes pagal atskirus išteklius ir funkcijas.

\section{REZULTATAI IR JŲ APTARIMAS}

\section{Lietuvos miško išteklių ir funkcijų ekonominis vertinimas}

Ivertinti Lietuvos miškus prognozuojant juose gaunamas pajamas ir daromas išlaidas ateityje šiuo metu problematiška dèl normatyvinių duomenų trūkumo. Tinkamiausia tokiam vertinimui yra medynų tūrio naudojimo prognozavimo normatyvinè bazè, tačiau pagrịstų duomenų apie miško auginimo pinigines išlaidas bei nemedieninių miško išteklių ir funkcijų vertinimo normatyvus trūksta arba duomenys nèra tikslūs. Todèl buvo atlikti preliminarūs Lietuvos miškų daugiafunkcinio naudojimo vertinimai taikant supaprastintus pajamu kapitalizavimo metodus bei esamą ịvairių šaltinių informaciją apie miškų naudojimo apimtis, pajamas ir išlaidas bei darant ịvairias prielaidas.

Mediena. Miškus pagal medieną galima vertinti kapitalizuojant miško įmonių grynąsias pajamas ir naudojant modifikuotą Faustmano formulę (3 formulè). Pateikiame abiejų variantų vertinimo duomenis.

Miško immonių grynosios pajamos apskaičiuotos pagal Ûkio ministerijos taikomą metodiką - grynojo pelno, turto ir žaliavų mokesčių sumą. $2011 \mathrm{~m}$. miškų urédijų grynasis pelnas buvo $28,3 \mathrm{mln}$. Lt, turto mokestis $-6,0 \mathrm{mln}$. Lt, o žaliavu mokestis $-75,0 \mathrm{mln}$. Lt. Iš viso grynosios pajamos sudare 109,3 mln. Lt, arba 20,0 \% miškų urédijų pardavimų pajamų dali $(545,5 \mathrm{mln}$. Lt).

Paskutinio dešimtmečio (2002-2011) grynųju pajamų metinis vidurkis sieke $81,2 \mathrm{mln}$. Lt (kasmetinès grynosios pajamos apskaičiuotos $20 \%$ nuo metinių pardavimų sumų). Papildomai miš$\mathrm{kų} \mathrm{urèdijos} \mathrm{turi} \mathrm{išlaidų} \mathrm{viešosioms} \mathrm{paslaugoms}$ užtikrinti. 2002-2011 m. jos sudarè vidutiniškai 23,4 mln. Lt per metus (GMU, 2011). Taigi bendra metinė grynųų pajamų suma būtų 104,6 mln. Lt, arba 26,2 \% pardavimų pajamų. Kapitalizavus šias 
grynąsias pajamas $(104,6 \mathrm{mln} . \mathrm{Lt})$ pagal $3 \%$ diskonto normą, gautas miškų urėdijų miškų ìvertinimas - 3486,7 mln. Lt. Ekstrapoliavus šią sumą visiems Lietuvos miškams, gauta jų vertė pagal medieną - 7029,2 mln. Lt.

Prielaidos:

1. Visos miškų urèdijų grynosios pajamos priskiriamos medienos naudojimui.

2. Nevalstybiniams miškams taikomi miškų urèdijų grynųjų pajamų rodikliai.

Taikant modifikuotą Faustmano formulę miškus vertinti pagal medieną galima:

1) pagal miško sklypų duomenis;

2) pagal medynų plotų pasiskirstymo amžiaus klasemis lenteles;

3) pagal vidutinius Lietuvos medynų duomenis.

Čia pateikiamas vertinimas pagal labiausiai supaprastintą 3 variantą. Neatsižvelgiama ił ugdymo kirtimų pajamas ir išlaidas. IV grupès medynų vertinimas pagal modifikuotą Faustmano formulę (4) pateiktas 1 lentelèje.

Analogiškai nustačius II ir III grupių medynų hektaro vertinimus ir taikant Lietuvos medynu pasiskirstymą pagal grupes ir vyraujančias medžių rūšis (2011-01-01), apskaičiuota Lietuvos miškų vertè pagal medieną $17248,7 \mathrm{mln}$. Lt, iš jų II gr. 349,9 mln. Lt, III gr. - 2 348,4 ir IV gr. 14550,4 mln. Lt.
Nemedieninių miško išteklių ir funkcijų metinès naudos vertinimas

Nemedieniniai miško ištekliai ir funkcijos vertinti dviem etapais:

1) metinès naudos ìvertinimas;

2) grynųų pajamų apskaičiavimas ir kapitalizavimas.

Miško grybai. Metinis eksploatacinis grybų derlius visuose Lietuvos miškuose sudaro 24,1 tūkst. t. Gyventojams surenkant 30-40 \% eksploatacinio grybų derliaus grybų paruošos Lietuvos miškuose galètu sudaryti apie 8500 t kasmet (Kuliešis, Rutkauskas, 2000). Grybų eksporto kaina 2001$2010 \mathrm{~m}$. buvo vidutiniškai 15,7 Lt/kg (Lietuvos miškų ūkio statistika, 2011). Visų surenkamų grybų kaina siektų 133,5 mln. Lt.

Miško uogos. Metiniai eksploataciniai miško uogu ištekliai visuose Lietuvos miškuose sudaro 4948 t (Kuliešis, Rutkauskas, 2000). 20012010 m. kasmet buvo superkama vidutiniškai 1155 t uogų (Lietuvos miškų ūkio statistika, 2005; 2011). Darant prielaidą, kad dar tiek pat miško uogu gyventojai surenka savo reikmèms, metinis miško uogų naudojimas būtų 2310 t. Miško uogų eksporto vidutinè kaina 2001$2010 \mathrm{~m}$. buvo 12,6 Lt/kg (Lietuvos miškų ūkio statistika, 2011). Visų (2 310 t) miško uogų kaina $-29,1 \mathrm{mln}$. Lt.

1 lentelè. Lietuvos miškų (IV grupè) vertinimas pagal medieną

Table 1. Evaluation of Lithuanian forests according to wood

\begin{tabular}{|c|c|c|c|c|}
\hline $\begin{array}{c}\text { Medynai } \\
\text { Stands }\end{array}$ & $\begin{array}{c}\text { Brandžių }{ }^{\star} \text { medynų } \\
\text { verte }^{\star \star} \mathrm{Lt} / \mathrm{ha}\left(A_{T}\right) \\
\text { Evaluation of mature } \\
\text { stands }\end{array}$ & $\begin{array}{c}\text { Miško atkūrimo } \\
\text { išlaidos }{ }^{\star * *} \mathrm{Lt} / \mathrm{ha}(C) \\
\text { Costs of reforestation }\end{array}$ & $\begin{array}{l}\text { Vidutinis } \\
\text { medynų } \\
\text { amžius }(t) \\
\text { Age }\end{array}$ & $\begin{array}{c}\text { Medynų verte் } \\
\text { Lt/ha }(M) \\
\text { Value of stands }\end{array}$ \\
\hline Pušynai / Pine & 31609 & 4281 & 65 & 9078 \\
\hline Eglynai / Spruce & 28674 & 4088 & 45 & 12273 \\
\hline Azžuolynai / Oak & 72281 & 7055 & 70 & 14153 \\
\hline Uosynai / Ash & 19364 & 1351 & 65 & 5586 \\
\hline Beržynai / Birch & 18226 & 1579 & 45 & 11702 \\
\hline Juodalksnynai / Black alder & 13314 & 1251 & 42 & 7367 \\
\hline Drebulynai / Aspen & 5763 & - & 43 & 7914 \\
\hline Baltalksnynai / Grey alder & 2120 & - & 32 & 2658 \\
\hline
\end{tabular}

${ }^{*} \mathrm{P}, \mathrm{U}-100$ metų / years; A - 120; E - 70; B, J - 60; D - 40; Bt - 30;

** nenukirsto miško 2012-12-13 kainomis / according to stumpage prices of 13.12.2012;

${ }_{* * *}$ Riepšas, Laurinavičius, 2009;

**** administracinès-valdymo metinès išlaidos / Administrative-management annual costs - LTL 35/ha, palūkanų norma $-3 \%$ / Interest rate $-3 \%$. 
Vaistiniai augalai. Miško vaistinès žaliavos metiniai eksploataciniai ištekliai Lietuvos miškuose - 3052 t (Kuliešis, Rutkauskas, 2000). 2001$2010 \mathrm{~m}$. kasmet buvo superkama 21,6 t žaliavos (Lietuvos miškų ūkio statistika, 2006; 2011). Darant prielaidą, kad dar tiek pat miško vaistinès žaliavos gyventojai surenka savo reikmèms, metinis šios žaliavos naudojimas būtų 53,2 t. Taikant vidutinę vaistažolių supirkimo kainą 24 Lt/kg (Petrošiūtè, 2010), jų kaina būtų 1,3 mln. Lt.

Medžiojamieji gyvūnai. 2001-2010 m. vidutiniškai kasmet buvo sumedžiojama: briedžių - 196, elnių - 941, stirnų - 15 908, šernų - 21 328, kiškių - 6 249, lapių - 15 346, bebrų - 9993 (Lietuvos miškų ūkio statistika, 2002-2011). Pagal medžioklès kainoraštị užsienio medžiotojams (2000-01-26) žvèriu sumedžiojimo kainos buvo: briedis - 1 756-6 783 Lt, elnias - 794-13 $835 \mathrm{Lt}$, stirna - 107-3 433 Lt, šernas - 883-2 719 Lt, bebras - $266 \mathrm{Lt}$, kiškis - $35 \mathrm{Lt}$, vilkas - $1760 \mathrm{Lt}$, mangutas - 207 Lt, kiaunè, lapè - 173 Lt. Briedžių, elnių, stirnų kainos skiriasi, priklausomai nuo ragų svorio, o šernų - nuo ilčių ilgio. Skaičiavimams imtas kainų intervalo vidurkis. Sumedžiotų žverrių ivertinimas buvo $88,7 \mathrm{mln}$. Lt.

Poilsiavimas miškuose. Poilsiavimui miškuose ivvertinti buvo taikytas kontingentinis metodas. Vertinimo pagrindas yra tiriamos populiacijos apklausa (Tidikis, 2003; Kardelis, 2007). Apklausos anketa buvo paruošta remiantis mokslineje literatūroje aprašytais anketinès apklausos bendraisiais sudarymo reikalavimais ir pasiūlymais. Lietuvos gyventojų apklausai atlikti buvo užsakytos viešosios nuomonès ir rinkos tyrimų bendrovès „Spinter tyrimai“ paslaugos. Tyrimas atliktas $2012 \mathrm{~m}$. kovo 27-31 d. Omnibus metodu. Ši apklausa - tai standartizuotas betarpiškas interviu naudojant klausimyną. Tyrimo lokacija buvo visa šalies teritorija - 75 atrankos taškai, kurie reprezentavo visus šalies regionus. Tyrime buvo apklausti 1007 nuo 18 iki 75 metų amžiaus respondentai. Tyrime naudotas daugiapakopès stratifikuotos tikimybinès atrankos metodas. Šis atrankos metodas užtikrino duomenų reprezentatyvumą, t. y. kiekvienas šalies namų ūkis turèjo vienodas galimybes būti apklaustu ir atrankinè visuma pagal tikslinius kriterijus atitiko generalinę visumą.

Pagal gyventojų apklausos duomenis metinis poilsiavimo dienų skaičius Lietuvos miškuose siekia 33,4 mln. dienų. Mokestị už lankymąsi miške sutiktų mokèti $12 \%$ lankytojų. Darant prielaidą, kad poilsiavimo diena vertintina pagal sutinkančiu mokèti duomenis (vidutiniškai už dieną - 3,53 Lt), metinis ịvertinimas būtų 117,9 mln. Lt.

Anglies dvideginio naudojimas. Pagal Lietuvos nacionalinès miškų inventorizacijos medynų plotuc ir tūrio prieaugio $2009 \mathrm{~m}$. duomenis buvo apskaičiuota, kad Lietuvos miškai kasmet sunaudoja vidutiniškai $12,7 \mathrm{mln}$. $\mathrm{t}_{2}$. $\mathrm{CO}_{2}$ sunaudojimo kaina buvo nustatyta naudojant prekybos $\mathrm{CO}_{2}$ taršos leidimais duomenis. $2012 \mathrm{~m}$. vidutine $\mathrm{CO}_{2}$ taršos leidimų rinkos kaina buvo 24,5 Lt/t. Metinẻ $\mathrm{CO}_{2}$ sunaudojimo vertè $-311,2 \mathrm{mln}$. Lt.

Biologinès ịvairovės išsaugojimas. Lietuvos rezervatų ir draustinių miškų funkcijos ịvertintos alternatyvių išlaidų metodu pagal miško naudojimo pajamų netekimus. Itvertintas I, II ir III mišku grupių metinių pagrindinių kirtimų sumažẻjimas, palyginti su alternatyva, jei šie miškai būtų ūkiniai: I gr. - 16,1 mln. Lt, II gr. - 179,5 mln. Lt ir III gr. $-60,0$ mln. Lt. I gr. miškai yra rezervatiniai, II gr. draustiniai sudaro $64,2 \%$, III gr. - 25,6 \% Metinių kirtimų vertès sumažèjimas, tenkantis rezervatiniams ir draustinių miškams - 146,7 mln. Lt $(16,1+179,5 \times 0,642+60,0 \times 0,256)$.

Lietuvoje išskirta 453,2 tūkst. ha „Natura 2000“ teritorijų, iš jų paukščų apsaugai svarbios teritorijos - 334,5 tūkst. ha, buveinių apsaugai svarbios teritorijos - 118,7 tūkst. ha. Buvo vertinti (Grigaliūnas, 2005) nuostoliai dèl biosferos poligonų išskyrimo Taujènų-Užulènio biosferos poligone (plotas - 22531 ha), kur išskirtos 37 paukščių veisimosi vietos, užimančios 281,3 ha plotą. Brandžių medynų vertė sudarè $6,9 \mathrm{mln}$. Lt. Brandūs medynai iškertami per 10 metų, tad vieneriems metams tenka $0,7 \mathrm{mln}$. Lt nuostolių. Ekstrapoliavus šiuos duomenis visoms „Natura 2000“ teritorijoms (453,2 tūkst. ha), metiniai nuostoliai sudarytų $14,1 \mathrm{mln}$. Lt.

Kertinių buveinių išskyrimo medienos nuostoliai ịvertinti Kẻdainių miškų urèdijoje (GMU, 2005). Kertinèse ir potencialiose kertinèse miško buveinèse (1 174 ha) brandžių medynų vertè - 17,8 mln. Lt. Vieneriems metams tektų 1,8 mln. Lt. Ekstrapoliavus šiuos duomenis visoms Lietuvos kertinèms buveinèms (26 $456 \mathrm{ha}$ ), metiniai pajamų nuostoliai sudarytų 40,6 mln. Lt.

Plynų kirtimų biržèse kasmet paliekama apie 100 tūkst. $\mathrm{m}^{3}$ biologinès ịvairovès medžių. Jų vertė - 9,6 mln. Lt. Bendri pajamų nuostoliai dèl biologinès įvairovès apsaugos miškuose $-(146,7+14,1+40,6+9,6) 211,0 \mathrm{mln}$. Lt. 
Vandenų apsauginès funkcijos. Vandens nuotèkio padidinimas. Vidutiniškai 1 ha miškų Pietryčių smèlètoje lygumoje padidina nuotèki $200-300 \mathrm{~m}^{3}$, kalvotame landšafte - $130-200 \mathrm{~m}^{3}$, o moreninèse lygumose - 70-100 $\mathrm{m}^{3}$ (Pauliukevičius, 1975).

Taikant vidutinį nuotèkio padidejjimą $185 \mathrm{~m}^{3} / \mathrm{ha}$ dèl 2,1 mln. ha miškų jis kasmet padidètų $388,5 \mathrm{mln} . \mathrm{m}^{3}$. Esant vieno kubinio metro vandens kainai - 0,007 Lt (Mokesčio už vandens išteklius įstatymas) šios funkcijos metinis įvertinimas būtų 2,7 mln. Lt.

Vandens apsauga nuo užteršimo kenksmingomis medžiagomis. Metinis mažai mineralizuoto vandens nuotèkis, patenkantis iš miškų, priemolingose lygumose atskiedžia apytikriai $22 \mathrm{~m}^{3}$, kalvotose žemèse $-29 \mathrm{~m}^{3}$ ir smèlio lygumose - apie $30 \mathrm{~m}^{3}$ gruntinio vandens (Pauliukevičius, 1975). Visiškas biologinis $1 \mathrm{~m}^{3}$ nutekamųu ų vandenų išvalymas kainuoja 3,51 Lt/m³ (UAB „Giraitès vandenys“, $2011 \mathrm{~m}$. tarifas). Priimant, kad 1 ha miško vidutiniškai atskiedžia $26 \mathrm{~m}^{3}$ vandens, šios miškų funkcijos verte Lietuvoje būtų 191,6 mln. Lt.

Paviršinio nuotekkio pervedimas ị gruntinị. Priemolio ir molio dirvožemiuose augantys miškai padidina gruntini vandens nuoteki $545 \mathrm{~m}^{3} /$ ha per metus (Karazija, Vaičiūnas, 2000). Lietuvoje priemolio ir molio dirvožemių miškai sudaro $24,4 \%$ (Kenstavičius, Brukas, 1984). Esant požeminio vandens kubinio metro kainai $0,06 \mathrm{Lt}$, viso nuotékio vertè būtų $16,8 \mathrm{mln}$. Lt.
Bendra miškų vandenų apsauginių funkcijų metinè vertè - 211,1 mln. Lt $(2,7+191,6+16,8)$.

Priešerozinè funkcija. Kalvotose žemèse (vidutinių nuolydžių 8-12 \%) kasmet nuplaunama apie 3,4-4 t/ha dirvožemio. Šiame dirvožemio kiekyje yra sukaupta cheminių medžiagų: apie $8 \mathrm{~kg}$ azoto, $36 \mathrm{~kg}$ kalio, $11 \mathrm{~kg}$ fosforo, $25 \mathrm{~kg}$ kalcio (Pauliukevičius, 1974). Darant prielaidą, kad priešeroziniuose miškuose (24,7 tūkst. ha) dirvožemis nenuplaunamas, maistinių medžiagų išsaugojimas būtų: $\mathrm{N}-198 \mathrm{t}, \mathrm{K}-889 \mathrm{t}$, $\mathrm{P}-271 \mathrm{t}, \mathrm{Ca}-618$ t. Jų vertè trąšų kainomis 2,5 mln. Lt.

Sanitarinès bei higieninès funkcijos. Pradiniai duomenys: 1 ha miško per vegetacijos laikotarpi sugeria vidutiniškai $44 \mathrm{t}$ dulkių. Dulkių susiurbimo ìrengimo (skruberio) kaina - 100 tūkst. Lt, eksploatacinès išlaidos $50 \%$, amortizacijos laikotarpis - 5 metai, našumas $-1 \mathrm{t}$ dulkiu per dieną. Metinès išlaidos 1 ha miško pakeitimui - 3617 Lt. Miestų miškų Lietuvoje yra 13070 ha. Jų dulkių sugèrimo funkcijos metinè vertè - 47,3 mln. Lt (3 $617 \mathrm{Lt} / \mathrm{ha} \times 13070 \mathrm{ha}$ ).

Miškų vertinimas pagal nemedieninius miško išteklius. Miškai pagal nemedieninius išteklius ir funkcijas ịvertinti jų metinès naudos vertinime išskiriant grynąsias pajamas ir jas kapitalizuojant. Taikyta grynųų pajamų norma 26,2 \% (20022011 m. miškų urẻdijų vidurkis) ir $3 \%$ palūkanų norma (2 lentelè).

\section{2 lentelè. Nemedieninių miško išteklių ir funkcijų vertinimas mln. Lt}

Table 2. Evaluation of non-wood products and functions, LTL mln.

\begin{tabular}{|c|c|c|c|}
\hline $\begin{array}{l}\text { Miško ištekliai ir funkcijos } \\
\text { Forest resources and functions }\end{array}$ & $\begin{array}{l}\text { Metinès naudos vertè } \\
\text { Annual value }\end{array}$ & $\begin{array}{l}\text { Grynosios pajamas } \\
\text { Net income }\end{array}$ & $\begin{array}{l}\text { Kapitalizuota vertè } \\
\text { Capitalisation value }\end{array}$ \\
\hline Miško grybai / Mushrooms & 133,5 & 35,0 & 1166,7 \\
\hline Miško uogos / Berries & 29,1 & 7,6 & 253,3 \\
\hline Vaistinè žaliava / Herbs & 1,3 & 0,3 & 10,0 \\
\hline Medžiojami gyvūnai / Hunting & 88,7 & 23,2 & 773,3 \\
\hline Rekreacija / Recreation & 117,9 & 30,9 & 1030,0 \\
\hline $\mathrm{CO}_{2}$ naudojimas / Carbon sequestration & 311,2 & 81,5 & 2716,7 \\
\hline $\begin{array}{l}\text { Biologinės ịvairovės išsaugojimas } \\
\text { Biodiversity conservation }\end{array}$ & 211,0 & 55,3 & 1843,3 \\
\hline $\begin{array}{l}\text { Vandenų apsauginès funkcijos } \\
\text { Water protection functions }\end{array}$ & 211,1 & 55,3 & 1843,3 \\
\hline Priešerozinè funkcija / Soil protection & 2,5 & 0,7 & 23,3 \\
\hline $\begin{array}{l}\text { Sanitarinès-higieninės funkcijos } \\
\text { Sanitary-hygienic functions }\end{array}$ & 47,3 & 12,4 & 413,3 \\
\hline Iš viso / Total & 1153,61 & 302,2 & 10073,2 \\
\hline
\end{tabular}


Kompleksinè ekonominè vertė. Pagal pateiktą metodiką apskaičiuota Lietuvos miškų ekonominè vertè - 27 321,9 mln. Lt (3 lentelè).

Skaičiavimų rezultatai patvirtino, kad miškų vertinimas labai priklauso nuo vertinimams taikomų metodų bei pradinių duomenų. Taikant skirtingus metodus miškams vertinti pagal medieną rezultatas skyrèsi 2,5 karto. Darbų, kuriuose buvo vertinami Lietuvos miškai, apžvalga parodè, kad nustatytos miškų vertès irgi dažnai skiriasi. Ūkio ministerija, skaičiuodama miškų urèdijų turto grąžą, miškus vertino 3,1 mlrd. Lt. Aleksandro Stulginskio universiteto tyrime (ASU, 2011) taikant Faustmano formulę su $3 \%$ diskonto norma valstybinių miškų vertè sieké 12,4 mlrd. Lt. Pagal valstybinių miškų apskaitos duomenis (2012-01-01) valstybiniai miškai ịvertinti 7,6 mlrd. Lt, o visi - 15,1 mlrd. Lt. Vertinimo metodo įtaka rezultatams galètų būti atskiro tyrimo objektas.

Didelius vertinimo skirtumus lemia diskonto norma. Minètame ASU tyrime, priklausomai nuo diskonto normos, valstybinių miškų vertè kito nuo 5,3 mlrd. Lt (diskonto norma 6,5 \%) iki 30,6 mlrd. Lt (diskonto norma $1 \%$ ).

Plètojant Lietuvos miškų ekonominị vertinimą reikètų vertinimo metodikas ir normatyvus itteisinti atitinkamuose teisès aktuose (standartuose, nurodymuose ar pan.). Toki požiūri yra išsakę J. T. Bishop (1998), P. K. Turner, J. Paavola, P. Cooper, S. Farber, V. Jessamy, S. Georgiou (2003), siūlydami priimti sprendimus politiniu lygmeniu, kurie aiškiai apibrèžtų miškų vertės nustatymo pozicijas. Lietuvoje galima rasti miškų ekonominio vertinimo reglamentuojančių teisès aktų sudarymo patirties (miškų vertinimas žemès reformos metu, nenukirsto miško kainų nustatymas, kompensacijos už ūkinès veiklos ribojimus miškuose bei keičiant tikslinę miško žemių paskirtį). Dabar aktualus yra miškų vertinimas, kaip įmonių turtas, miškų pirkimo bei pardavimo sandoriuose, komercionalizuojant nemokamai naudojamus miško išteklius ir funkcijas, miško ūkio ekonominejje analizeje.

\section{IŠVADOS IR SIŪLYMAI}

1. Universalaus, visuotinai pripažinto miškų išteklių ir funkcijų ekonominio vertinimo metodo nèra.

2. Miškų ekonominio vertinimo metodai skirstomi i dvi grupes:

a) kai miškų teikiama nauda yra rinkos objektas;

b) kai teikiama nauda nèra toks objektas.

Vertinant rinkoje dalyvaujančius miškų produktus ir paslaugas taikomos ju rinkos kainos. Nedalyvaujančių rinkoje miškų naudos vertinimui taikomi kontingentinis, kelionès išlaidų, hedoninio ìkainojimo, gamybos funkcijų bei išlaidomis grindžiami metodai.

3. Ekonominio vertinimo tikslams siūloma tokia Lietuvos miško išteklių ir funkcijų klasifikacija: mediena, miško grybai, miško uogos, miško vaistiniai augalai, medžiojamieji gyvūnai, miško

3 lentelè. Lietuvos miškų bendroji ekonominè vertė

Table 3. Total economic value of Lithuanian forests

\begin{tabular}{|c|c|c|}
\hline \multirow{2}{*}{$\begin{array}{l}\text { Miško ištekliai ir funkcijos } \\
\text { Forest resources and functions }\end{array}$} & \multicolumn{2}{|c|}{ Vertè / Value } \\
\hline & mln. Lt & $\%$ \\
\hline Mediena / Wood & 17248,7 & 63,1 \\
\hline Miško grybai / Mushrooms & 1166,7 & 4,3 \\
\hline Miško uogos / Berries & 253,3 & 0,9 \\
\hline Vaistinè žaliava / Herbs & 10,0 & 0,0 \\
\hline Medžiojamieji gyvūnai / Hunting & 773,3 & 2,8 \\
\hline Poilsiavimas miškuose / Recreation & 1030,0 & 3,8 \\
\hline $\mathrm{CO}_{2}$ naudojimas / Carbon sequestration & 2716,7 & 9,9 \\
\hline Biologinès įvairovès išsaugojimas / Biodiversity conservation & 1843,3 & 6,8 \\
\hline Vandenų apsauginès funkcijos / Water protection functions & 1843,3 & 6,8 \\
\hline Priešerozinè funkcija / Soil protection & 23,3 & 0,1 \\
\hline Sanitarinès-higieninès funkcijos / Sanitary-hygienic functions & 413,3 & 1,5 \\
\hline Iš viso / Total & 26655,2 & 100,0 \\
\hline
\end{tabular}


rekreacinès funkcijos, $\mathrm{CO}_{2}$ naudojimas, biologinès ivvairovès išsaugojimas, vandenų apsauga, priešerozinès funkcijos, laukų apsauginès funkcijos, sanitarinès bei higieninès funkcijos.

4. Žaliavinių miško išteklių naudojimo pajamas siūloma apskaičiuoti remiantis jų produktų rinkos kainomis. Miško rekreacinių išteklių vertinimui siūloma taikyti kontingentinio vertinimo metodą. $\mathrm{CO}_{2}$ sunaudojimui vertinti - taršos leidimu kainas. Biologinès ịvairovès išsaugojimo funkcijai - alternatyvių išlaidų metodą. Vandenų apsauginèms funkcijoms, priešerozinèms ir sanitarinèms bei higieninèms miško funkcijoms - išvengtų išlaidų bei produktyvumo pokyčių metodus.

5. Nustatytas didelis miškų įvertinimo pagal medieną skirtumas taikant faktinius miško įmonių grynųjų pajamų rodiklius ir vertinant pagal Faustmano formulę.

6. Pagal taikytus vertinimo metodus ir turimą informaciją nustatyta 26,7 mlrd. Lt Lietuvos miškų ekonominè vertè. Nemedieniniai ištekliai ir funkcijos sudaro 36,9 \% Lietuvos miškų vertès. Iš miško funkcijų daugiausia ịvertinta $\mathrm{CO}_{2}$ naudojimas $(9,9 \%)$, biologinès ịvairovès išsaugojimas ir vandens apsauginès funkcijos (po 6,8\%).

7. Reikètų reglamentuoti miško išteklių ir funkcijų ekonominio vertinimo metodus.

Gauta 20130312

Priimta 20130617

\section{LITERATŪRA}

1. ASU. 2011. Valstybinès reikšmès miškų vertinimo metodikos parengimas ir jos pritaikymas bei turto grąžos iš miško vertinimo rekomendacijos ES šalių patirties kontekste: ataskaita. Vadovas R. Deltuvas (rankraštis). $40 \mathrm{p}$.

2. Binkley C. S. 2009. The Sensitivity of the Value of Timberland Assets to Changes in the Discount Rate. IFIA Working Paper. 5 p. [žiūrèta 201110-26]. Prieiga per internetą: http://www.ifiallc. com/PDFs/The-Sensitivity-of-the-Value-ofTimberland-Assets-to-Changes-in-the-DiscountRate.pdf

3. Bishop J. T. 1998. The Economics of Non-timber Forest Benefits: An Overview. Environmental Economic Programme GK 98-01. 21 p. [žiūrèta 2012-11-15]. Prieiga per internetą: http://pubs. iied.org/pdfs/8102IIED.pdf
4. Brukas V., Thorsen B. J., Helles F., Tarp P. 2001. Discount rate and harvest policy. Forest Policy and Economics. Vol. 2. P. 143-146.

5. Čiegis R. 2008. Darnus ekonomikos vystymasis. Šiauliai. 205 p.

6. Čiegis R. 2009. Gamtos ištekliu ir aplinkos ekonomika. Klaipèda. 772 p.

7. Deltuvas R. 2008. Miškonaudos teoriniai pagrindai. Miško naudojimas ir logistika. Akademija. P. 11-98.

8. Dieterich V. 1953. Forst-Wirtschaftspolitik. Verlag Paul Parey. 398 p.

9. EC. 2009. International Accounting Standard 41. 8 p. [žiūrèta 2012-06-20]. Prieiga per internetą: http://ec.europa.eu/internal_market/accounting/ docs/consolidated/ias41_en.pdf

10. EK. 2006. Ekonominès naudos analizès atlikimo metodinès gairès. Metodiniai darbo dokumentai (Darbo dokumentas Nr. 4. 22 p.) [žiūrèta 2011-0616]. Prieiga per internetą: http://www.esparama.lt/ es_parama_pletra/failai/fm/failai/Ekonomines_ naudos_gaires/wd4_cost_lt.pdf

11. Ekonomikos institutas. 1975. Miško žemiu ekonominis vertinimas. Vilnius: Pergalè. 192 p.

12. GMU. 2005. Biologinès ịvairovès išsaugojimas [žiūrèta 2005-10-20]. Prieiga per internetą: http:// www.gmu.lt/?pid=257

13. GMU. 2011. Valstybès turto panaudojimo efektyvumas valstybiniuose miškuose. 26 p. [žiūrèta 2012-11-15]. Prieiga per internetą: http://www. gmu.lt/images/default/source/attachments/ Naujienos/2011-09-28_pristatymas_seimo_biudzeto_ir_finansu_komitetui.pdf

14. Grege-Staltmane E., Tuherm H. 2010. Importance of discount rate in Latvian forest valuation. Baltic Forestry. Vol. 16. No. 2. P. 303-311.

15. Grigaliūnas J. 2005. Miško ūkinès veiklos ịtaka ir ypatumai saugomu paukščiu populiacijoms VI Ukmergès mišku urédijoje. Lietuvos miškų institutas (rankraštis). 95 p.

16. Hepburn C. J., Koundouri P. 2007. Recent advances in discounting: implications for forest economic. Journal of Forest Economics. Vol. 13. Issue 2-3. P. 169-189.

17. Hogg J. N., Jöbst H. A. 2005. International interdependencies of the forestry accounting system and their effects on business management. In.: H. A. Jöbstl (ed.). Contributions to Forestry Accounting. Vienna: University of Natural Resources and Applied Life Sciences. P. 25-40.

18. Homo Sanitus. 2012. Apie atmosferos deguoni [žiūrèta 2012-05-15]. Prieiga per internetą: http:// www.homosanitus.lt/lt/Animizmas/turinys/kokteilis/apie_atmosferos_deguoni

19. Karazija S., Vaičiūnas V. 2000. Ekologinis mišku vaidmuo. Kaunas. 150 p.

20. Kardelis K. 2007. Mokslinių tyrimų metodologija ir metodai: vadovèlis. Šiauliai: Lucilijus. 397 p. 
21. Kenstavičius J., Brukas A. 1984. Lietuvos TSR mišku tvarkymo augimviečiu pagrindu rezultatas ir rekomendacijos jam tobulinti. Vilnius. $420 \mathrm{p}$.

22. Klemperer W. D. 1996. Forest Resource Economics and Finance. New York. 552 p.

23. Kuliešis A., Rutkauskas A. 2000. Miškotvarka-daugiatikslio miško naudojimo kontekste. Aplinkos vertybių integracija ị Lietuvos miško ūkị. Danijos karališkasis veterinarijos ir žemès ūkio universitetas. Miškotyros diskusiniai darbai. Nr. 30. P. 139150.

24. Martinkus B., Žilinskas V. 1997. Ekonomikos pagrindai. Kaunas: Technologija. 705 p.

25. Merlo M., Croitoru L. 2005. Concepts and methodology: a first attempt towards quantification. In: Mediterranean Forests: Towards Total Economic Value. Oxfordshire, UK; Cambridge, USA. P. 1736.

26. Miškininkystė. 1979. Sud. L. Kairiūkštis ir kt. Vilnius. $312 \mathrm{p}$.

27. Mizaras S. 2006. Lietuvos miškų metinès naudos bendroji ekonominè vertè. Miškininkystè. Nr. 2(60). P. 27-34.

28. Pauliukevičius G. 1974. Lietuvos TSR miškų apsauginių funkcijų ekonominè reikšmè. Girios. Nr. 12. P. 8-11.

29. Pauliukevičius G. 1975. Miško apsauginių funkcijų vertinimo skalès sudarymas. Miško žemiu ekonominis vertinimas. Vilnius. 132-143 $\mathrm{p}$.

30. Price C. 1993.Time, Discounting and Value. Oxford, UK. 393 p.

31. Tidikis R. 2003. Socialiniu mokslu tyrimu metodologija: vadovèlis. Vilnius: Lietuvos teisès universitetas. $627 \mathrm{p}$.

32. Turner R. K., Paavola J., Cooper P., Farber S., Jessamy V., Georgiou S. 2003. Valuing nature: lessons learned and future research directions. Ecological Economics. Vol. 46. P. 493-510.

33. Weitzman M. L. 1998. Why the far distant future should be discounted at its lowest possible rate. Journal of Environmental Economics and Management. No. 36. P. 201-208.

34. Uilliams M. R. V. 1991. Racionalnoe ispolzovanie lesnykh resursov. Ekologiya. Moskva. $126 \mathrm{~s}$.

\section{Stasys Mizaras, Marius Kavaliauskas, Gintautas Činga \\ ECONOMIC ASSESSMENT OF MULTIFUNCTIONAL FORESTS USING DIRECT INCOME CAPITALIZATION APPROACH}

\section{Summary}

Direct income capitalization approach is one of the valuation methods of asset and the adaptation of this method to evaluate the forest is a complicated matter because of multifunctionality.

The following classification of forest functions and resources were used in this study: wood, mushrooms, berries, herbs, hunting, recreation, carbon sequestration, biodiversity conservation, water protection, soil protection, sanitary-hygienic functions.

The capitalization of forest enterprises net income and the Faustmann formula were used to evaluate Lithuanian forests in accordance with wood. The following two stages were applied to evaluate forests regarding non-wood products and functions: 1) annual benefit evaluation; 2) net income calculation and capitalization.

In the process of forest land area evaluation using the direct income capitalization approach, the income and costs of mature stands that are allowable to cut were prognosticated. The income and costs were capitalized. The net discounted revenue was calculated as the subtraction of income from costs. Analogous with the prognostic value, estimation of net discounted revenue from subsequent rotations was made. Therein the value of forest land area was calculated as the composition of discounted cash flow of present and future stands.

During the evaluation of forest enterprises, the net annual income was discounted and capitalized. The direct income from timber resources was evaluated using market prices. Forest recreation was evaluated using the contingent valuation method. The value of emission permits were used to evaluate carbon sequestration. The value of biodiversity was estimated using the method of alternative costs. Water protection, soil protection and sanitary-hygienic functions were evaluated using the avoided cost method and the method of productivity change.

The results of the research showed that the total economic value of Lithuanian forests was LTL 26.7 billion (wood evaluated using Faustmann formula). 36.9\% out of the total economic value were non-wood forest products.

Key words: forest, resources, functions, income capitalization, evaluation 